\title{
The Impact of Political Risk on Foreign Direct Investment
}

\author{
Mashrur M. Khan ${ }^{1} \&$ Mashfique Ibne Akbar ${ }^{2}$ \\ ${ }^{1}$ International Food Policy Research Institute, Bangladesh \\ ${ }^{2}$ Centre for Policy Dialogue, Bangladesh \\ Correspondence: Mashrur M. Khan, International Food Policy Research Institute, House: 10A, Road: 35, \\ Gulshan 2, Dhaka 1212, Bangladesh. Tel: 880-177-611-1158. E-mail: mashrur.m.khan@gmail.com
}

Received: May 27, 2013

Accepted: June 13, 2013

Online Published: July 26, 2013

doi:10.5539/ijef.v5n8p147

URL: http://dx.doi.org/10.5539/ijef.v5n8p147

\begin{abstract}
Political risk, like all other risks, has an adverse effect on any economy. Even though other forms of risk, such as economic risk and financial risk have been studied quite extensively, political risk has not received much attention owing primarily to lack of data. The current paper attempts to study a negative and significant relationship between political risk and Foreign Direct Investment (FDI), accounting for 94 countries over a span of 24 years from 1986-2009. It was found that most of the political risk indicators have a negative relationship with FDI for the world as a whole and also, the high-income countries but the relationship was the strongest for the upper middle-income countries.
\end{abstract}

Keywords: political risk, foreign direct investment, panel data analysis

\section{Introduction}

Foreign Direct Investment (FDI) has been a subject of interest for decades. The influx of FDI surged primarily in the 1980s when lending by commercial banks to the developing economies dried up, which forced most countries to ease restrictions and offer tax incentives and subsidies to attract foreign capital (Aitken and Harrison, 1999; World Bank, 1997a, b). Consequently, FDI contributes positively to the Gross Domestic Product (GDP) of the host countries by bringing in foreign exchange reserves and improvement of the Balance of Payment (BoP) for the local economies. The rate of technological progress enhances with FDI since foreign firms bring in more advanced technology and management practices to the host countries (Findlay, 1978). Romer (1993) further adds that FDI can ease the transfer of technological and business know-how to the less developed economies with the consequent reduction of the 'idea gaps' between rich and poor countries. In addition, the new ideas can 'spill over' to other sectors and segments of the economy which are not FDI recipients; thereby, boosting the productivity of more firms in the process (Rappaport, 2000).

Theoretically, the two most important determinants of FDI are the size and growth of the host country and cost competitiveness. Empirical studies determined market size, wages and political stability to affect the location decisions of FDIs (Dunning 1993). Taking the case of Western Europe in the 1950s, Reuber et al. (1973) found that the determinants of US FDI depended mainly on liberal host government policies, technological infrastructure, skilled labour and cultural proximity. Additionally, Froot and Stein (1991) found real exchange rate to be a significant factor affecting FDI. The $\mathrm{O}$ (ownership) L (location) I (internalization) paradigm regarding a firm's motivation for investment in foreign countries, Dunning (1998) states that the ownership and internalization advantages are derived using firm-specific resources and capabilities, in conjunction with reduction in transaction costs, while location advantages refer to the ability to capture broader markets and resources.

Despite numerous studies identifying determinants of FDI, one factor remains to receive much attention owing primarily to high quality data - political risk (Note 1). Logically, it should be the case that political risk would have a significant negative impact on FDI. Political instability increases uncertainty in the economic environment, thereby lowering the incentives for foreign investors to invest in the host country.

International Country Risk Guide (ICRG) has disseminated separate financial, economic, and political ratings over the period 1984-2009 and has identified twelve different political risk indices. Theoretically, there seems to be a relationship between FDI and political risks, which is precisely the analysis undertaken in the current study. 
The next section reviews the existing literature on the subject and evidence from the results. Section 3 discusses the underlying theory and specifies the models to be employed in the study along with the estimation techniques. Section 4 provides the regression results with interpretations, and section 5 concludes the paper.

\section{Literature Review}

It should be noted at the outset that very few authors have tried to measure the impact of risk factors on FDI. The primary hindrance associated with risks is their quantitative measurements. Click (2005), in an attempt to measure political risk, deducted financial risks from total country risks to calculate political risks. The standard deviation of each country's regression residuals was assumed to provide a measure of the unexplained country risk, i.e. the unobserved political risk. The study showed differences in Return on Assets (ROA) related to measurable financial risk variables. To further examine whether country risk captured political risk, correlations of residual deviations were computed by the author with other country and political risk indicators. Consequently, it was revealed that the correlation between residual deviations and average Euro money, Institutional Investor and ICRG ratings was moderately high, establishing the notion of a significant correlated relationship. The author concluded that political risk is unrelated to ROA of the companies.

Hayakawa et al. (2011) examined the impact of various components of political as well as financial risk on inward FDI, from both long- and short-run perspectives, using risk indices from PRS. The paper employs the dynamic Generalized Method of Moments (GMM) estimator with data from 90 countries for the period 1985-2007 and focused most of their findings on developing countries. They found that among the political risk components, government stability, socioeconomic conditions, investment profile, internal and external conflict, corruption, religious tensions, democratic accountability, and ethnic tensions are closely associated and positively related with FDI flows. Among the financial risk components, only exchange rate stability yields statistically significant positive coefficients when estimated only for developing countries, implying that greater exchange rate stability leads to greater FDI into the host countries. Interestingly, most financial risk indicators yielded a negative or statistically insignificant relationship with FDI flows.

Busse and Hefeker (2005) explore the linkages between political risk, institutions and foreign direct investment inflows using data from 83 countries for the period 1984-2003 using different econometric techniques such as fixed effects and GMM estimator. They found that government stability, law and order, quality of the bureaucracy investment profile, internal and external conflict, ethnic tensions and democratic accountability are statistically significant determinants of foreign investment flows. Across different econometric models, the relative magnitude of the coefficients are largest for government stability and law and order, indicating that changes in these components of political risk and institutions are highly relevant for investment decisions of multinationals.

Other studies have deployed "corruption" as a measure of political risk and calculated its impact on FDI. Corruption has a disincentive effect on investment since it increases the risk and uncertainty encountered by potential investors (Getz and Volkema, 2001), thereby, discouraging investors to make further investments in such political risky economies. Habib and Zurawicki (2002) examined the impact of corruption on FDI and found a negative impact of corruption on FDI. The results suggest that foreign investors generally avoid corruption because of moral obligations and also the operational inefficiencies that arise due to corruption. Wei (2000) analyzed data on FDI in the early 1990s from 12 source countries and 45 host countries. Corruption revealed to have a significant and negative effect on FDI. Mauro (1995) also found corruption to have a negative impact on investment, thus resulting in diminished economic growth. However, studies such as Nye (1979), found that corruption has a positive impact on economic growth and development while Hines (1995) derived a non-significant relationship. Thus, the present study aims to explore the political risk indices and learn the respective indicators' impact on FDI.

\section{Theoretical Estimations and Modelling}

The present study attempts to capture the effect of political risk on FDI controlling for GDP, which is taken to account for the economic growth of a country. FDI stocks have been considered as the dependent variable for all the countries considered in the study (Note 2). We measure the FDI stocks in terms of USD in current prices and current exchange rates. Data was collected for 94 countries over a span of 24 years from 1986-2009. The countries were then classified into four groups based on GDP per capita (Appendix A-1).

Theoretically, the larger the size of the market and more the overall GDP, the more profits are to be made by foreign investors and, hence, the higher the FDI (Note 3). Therefore, one of the control variables for the current paper is GDP (Note 4). Another important factor affecting FDI is the openness of the economy (openness is denoted by the amount of exports and imports over GDP (Note 5)). Both GDP and openness are expected to have 
a positive relationship with FDI leading to higher economic growth and better standards of living.

It is the case that higher political risk might arise in different circumstances such as, political instability, poor law and order, etc. The higher the political risk, the higher the probability that the investment in the host economy will decrease. Hence, political risk can be stated to be a significant factor affecting FDI.

Thus, the model (unadjusted for individual and/or time specific effects) is:

$$
F D I_{i t}=\alpha+\beta_{1} G D P_{i t}+\beta_{2} \text { openness }_{i t}+\beta_{3} P R_{k i t}+e_{i t}
$$

where,

$F D I=\log$ of $F D I$ measured in current prices and current exchange rates

$G D P=\log$ of $G D P$ measured in current USD

Openness $=$ Log of Openness measured in current prices

$P R_{k}=\log$ of the Political Risk Component $k$ of country $i\left(P R_{k i}\right)$

$\left(P R_{k}\right)$, where $k$ refers to one of twelve different indices viz. Government Stability, Socioeconomic Conditions, Investment Profile, Internal Conflict, External Conflict, Corruption, Military in Politics, Religion in Politics, Law \& Order, Ethnic Tensions, Democratic Accountability and Bureaucracy Quality. To eliminate zero values so that logarithm exists, 1 has been added to all the political risk indices; and

$i t=$ country $i$, year $t$.

\subsection{Estimation Techniques}

Log is taken of all the four variables (FDI, GDP, Openness and Political Risk indices) with an aim to stabilize variance and make symmetric distributions so that the respective coefficients are not influenced by extreme values. It is to be noted that one political risk component is examined at a time to measure the effects of individual political risk indices and evade the high correlation between them. Moreover, the original indices indicated that the higher the index, the lower the political risk. However, to ease the interpretation of results, the maximum value of each of the indicator was deducted from the existing values to ensure that higher indices reflected higher political risks.

Since the study examines a range of countries over a span of time, panel data is a more appropriate methodology for the study. Five different estimation techniques have been used, namely, Pooled OLS, One-Way and Two-Way Fixed Effects Model and One-Way and Two-Way Random Effects Model.

Pooled OLS runs a simple OLS regression by stacking the time series data of the cross-sections, one above another. Thus, we estimate the following model:

$$
F D I_{i t}=\alpha+\beta_{1} G D P_{i t}+\beta_{2} \text { openness }_{i t}+\beta_{3} P R_{k i t}+e_{i t}
$$

where the symbols represent the same elements as mentioned before.

In order to explore if country-specific factors (like government policy, investment climate, etc.) affect FDI, we use the One-Way Fixed Effects Model. This model recognizes that different cross-sectional elements will have different attributes not captured in the model but assumes that for a given cross section, they will remain time-invariant. The effect of these attributes is captured in the intercepts. Thus, the model we estimate through this approach is:

$$
F D I_{i t}=\alpha_{i}+\beta_{1} G D P_{i t}+\beta_{2} \text { openness }_{i t}+\beta_{3} P R_{k i t}+e_{i t}
$$

where the $i$ of the intercept indicates the unobserved individual country-specific factors which is assumed to remain fixed over time (the other variables representing the same variables as before).

Two-Way Fixed Effects Model examines both country-specific and time-specific (exchange rates, oil prices, etc.) dimensions. It considers the effects of both individual-variant and time-variant attributes, thereby leading to better parameter estimates (Gujarati 2003).

Also, the model eliminates omitted variable bias. Hence, the model for this approach is:

$$
F D I_{i t}=\alpha_{i t}+\beta_{1} G D P_{i t}+\beta_{2} \text { openness }_{i t}+\beta_{3} P R_{k i t}+e_{i t}
$$

where the $i$ and $t$ of the intercept capture both the country-specific and time-specific attributes (the other variables representing the same elements as before).

Moving on, the Random Effects models capture individual or time-specific effects through the random error term. In the Random-Effects model, the intercept represents the mean value of the cross-section intercepts and the 
error component represents the random deviation of individual intercept from the mean value (Gujarati 2003). One-Way Random Effects model captures only the individual-specific effects and assumes them to be time-invariant.

The model estimated here is:

$$
F D I_{i t}=\alpha+\beta_{1} G D P_{i t}+\beta_{2} \text { openness }_{i t}+\beta_{3} P R_{k i t}+u_{i}+e_{i t}
$$

where $u_{i}$ captures individual-specific random effects (and the other variables represent the same elements as before). Two-Way Random Effects model captures both country and time-specific effects. Therefore, another error component $v_{t}$ is added to the regular error term in the model to capture time-specific random effects. Therefore, the model is:

$$
F D I_{i t}=\alpha+\beta_{1} G D P_{i t}+\beta_{2} \text { openness }_{i t}+\beta_{3} P R_{k i t}+u_{i}+v_{t}+e_{i t}
$$

where $v_{t}$ captures the time-specific effects (the other variables representing the same elements as mentioned previously).

With an array of models available for estimation, the best model has to be chosen from the available estimation techniques. Pooled OLS can be negated though, since individual-specific or time-specific effects prevail across the countries that might not be captured in the model specification. However, whether to capture these individual-specific and time-specific effects in the intercept or in a random error component can be deduced using specification tests. The decision rules for each of the specification tests follow in the discussion.

High Breusch-Pagan Lagrange Multiplier (LM) test statistics with associated low $p$-values deduce substantial cross-section variation and rejects the null hypothesis of homoskedastic pooled OLS. Accordingly, high F-test statistic with low $p$-values in the Fixed Effects models rejects the null hypothesis of no fixed effects. On the other hand, high Hausman test statistic, denoted by $m$, and low $p$-values in Random Effects models imply the null hypothesis of no correlation between the regressors, ultimately rejecting the individual effects.

\section{Empirical Results}

For the World and sub-divisions of countries (list of countries attached in Appendix A-1), the One-Way and Two-Way Fixed Effects models are preferred over Random-Effects Models since the null hypothesis of no fixed effects is rejected (with regard to $F$-tests) and the null hypothesis of no correlation (with regard to $m$ ) is rejected at the same time. Hence, it can be stated that the fixed effects are, therefore, the better models for the currently considered dataset.

\subsection{World}

Regression results display GDP and Openness to be significant, that too at $1 \%$ significance level, with almost all the estimation models and all the political risk indicators. GDP and Openness have a positive relationship with FDI and hence, this was one of the reasoning to consider the formers as the control variables for the respective regressions.

\begin{tabular}{|c|c|c|c|c|}
\hline \multicolumn{5}{|c|}{ World } \\
\hline \multirow{2}{*}{ Political Risk Components } & \multicolumn{2}{|c|}{ One-way Fixed } & \multicolumn{2}{|c|}{ Two-way Fixed } \\
\hline & Significant & Insignificant & Significant & Insignificant \\
\hline Government Stability & $-0.31 * *$ & & & 0.036 \\
\hline Socioeconomic Conditions & $-0.17 * * *$ & & $-0.30 * * *$ & \\
\hline Investment Profile & $-0.33 * * *$ & & & -0.07 \\
\hline Internal Conflict & & -0.028 & & 0.023 \\
\hline External Conflict & & 0.004 & & 0.017 \\
\hline Corruption & $0.55 * * *$ & & $0.13 * *$ & \\
\hline Military in Politics & $0.195 * * *$ & & $0.195 * * *$ & -0.001 \\
\hline Religion in Politics & & 0.002 & & -0.024 \\
\hline Law and Order & & -0.02 & $-0.156 * * *$ & \\
\hline Ethnic Tensions & & -0.009 & & -0.066 \\
\hline Democratic Accountability & & -0.007 & & 0.061 \\
\hline Bureaucratic Quality & & 0.074 & $-0.21 * * *$ & \\
\hline
\end{tabular}

Table 1. Summary of parameter estimates of political risk indicators on FDI

$* * *$ indicates significance at $1 \%$ significance level, ** indicates significance at $5 \%$ significance level $*$ indicates significance at $10 \%$ significance level

As can be seen from the table above (Table 1), political risk indicators, in the form of Government Stability, Socioeconomic Conditions and Investment Profile showed strong negative relationship with FDI for the 
One-way Fixed Effects Model. This is in line with the hypothesis that political risk has a negative impact on FDI. Corruption and Military in Politics also showed significance, although with a positive coefficient, implying that an increase in the respective indicators would actually lead to increased FDI, controlling for individual effects. The majority of the remaining indicators were insignificant, although having a negative relationship with FDI.

For the Two-Way Fixed Effects model, Socioeconomic Conditions, Law and Order and Bureaucratic Quality displayed significant negative results. Law and Order and Bureaucratic Quality were not significant in One-Way Fixed Effects model, indicating time-specific effects to impact these indicators, and imposing a negative effect on FDI. However, in line with the One-Way Fixed Effects model, Corruption and Military in Politics showed positive relationship, establishing the impact of these two political risk factors on FDI.

\subsection{High Income Countries}

A summary of the results of the detailed regression results for high-income countries (HICs) is presented in Table 2. Similar to the World, the FDI of HICs also exhibited positive significant relationship (at $1 \%$ significance level) with GDP and Openness. In terms of Political Risk indicators, Government Stability, Socioeconomic Conditions and Investment Profile showed significant negative relationship with FDI, for the One-Way Fixed Effects Model. Corruption, Military in Politics, Religion in Politics, Ethnic Tensions and Bureaucratic Quality showed positive significant relationship with FDI. Except the last three Political Risk indicators, the former indicators are in line with the World dataset outcome. Compared to the World, the HICs incorporate less insignificant variables. Now, with the segregation of economies, the results become more concrete. The Two-Way Fixed Effects Model shows significant indicators with a negative coefficient-significant indicators having a positive coefficient in the One-Way Fixed Effects Model take up the negative coefficient.

Table 2. Summary of results of the parameter estimates of political risk indicators on FDI

\begin{tabular}{|c|c|c|c|c|}
\hline \multicolumn{5}{|c|}{ High-Income Countries } \\
\hline Political Risk Components & \multicolumn{2}{|c|}{ One-way Fixed } & \multicolumn{2}{|c|}{ Two-way Fixed } \\
\hline & Significant & Insignificant & Significant & Insignificant \\
\hline Government Stability & $-0.18 * * *$ & & & -0.066 \\
\hline Socioeconomic Conditions & $-0.37 * * *$ & & $-0.17 * *$ & \\
\hline Investment Profile & $-0.24 * * *$ & & $0.26^{* * *}$ & \\
\hline Internal Conflict & & -0.001 & & -0.07 \\
\hline External Conflict & & 0.07 & $-0.09 * *$ & \\
\hline Corruption & $0.26^{* * *}$ & & & -0.11 \\
\hline Military in Politics & $0.16^{* *}$ & & $0.23 * * *$ & \\
\hline Religion in Politics & $0.32 * * *$ & & $0.17 * *$ & \\
\hline Law and Order & & 0.03 & $-0.16^{* * *}$ & \\
\hline Ethnic Tensions & $0.13 * *$ & & $-0.16 * * *$ & \\
\hline Democratic Accountability & & 0.07 & & 0.09 \\
\hline Bureaucratic Quality & $0.29 * *$ & & & 0.08 \\
\hline
\end{tabular}

\subsection{Upper Middle Income Countries}

A sum up of the regression results for upper middle-income countries (UMICs) is presented in Table 3.

Interestingly, for the UMICs, the Two-Way Fixed Effects model showed negative relationship between Openness and FDI, while keeping to the positive relationship between GDP and the latter. The economic implication for this may be explained by the substitutability between exports and imports and FDI. It is the case that exports together with imports increased with lesser dependence on FDI. However, the hypothesis is consistent for the other four models under consideration, that is, the relationship being negative and significant.

For the UMICs, Government Stability, Investment Profile and Ethnic Tensions showed negative and significant relationship with FDI. However, other significant Political Risk indicators including Socioeconomic Conditions, External Conflict, Corruption, Law and Order and Bureaucratic Quality showed positive and significant relationship with FDI. This could be because of the upward trend of FDI in these countries over the last few decades. Hence, political risk indicators have not been as significant a factor in these countries as they have been in the HICs. 
Table 3. Summary of results of the parameter estimates of political risk indicators on FDI

\begin{tabular}{|c|c|c|c|c|}
\hline \multicolumn{5}{|c|}{ Upper Middle-Income Countries } \\
\hline \multirow{2}{*}{ Political Risk Components } & \multicolumn{2}{|c|}{ One-way Fixed } & \multicolumn{2}{|c|}{ Two-way Fixed } \\
\hline & Significant & Insignificant & Significant & Insignificant \\
\hline Government Stability & $-0.31 * * *$ & & & 0.14 \\
\hline Socioeconomic Conditions & $0.59 * * *$ & & & 0.068 \\
\hline Investment Profile & $-0.20 * *$ & & $0.359 * * *$ & \\
\hline Internal Conflict & & -0.04 & & 0.07 \\
\hline External Conflict & $0.13 * *$ & & $0.27 * * *$ & \\
\hline Corruption & $0.81 * * *$ & & $0.23^{*}$ & \\
\hline Military in Politics & & 0.09 & $0.34 * * *$ & \\
\hline Religion in Politics & & -0.01 & $0.25 * * *$ & \\
\hline Law and Order & $0.32 * * *$ & & & -0.10 \\
\hline Ethnic Tensions & $-0.27 * *$ & & & -0.06 \\
\hline Democratic Accountability & & 0.06 & & 0.11 \\
\hline Bureaucratic Quality & $0.23 *$ & & & 0.02 \\
\hline
\end{tabular}

Table 4. Summary of results of the parameter estimates of political risk indicators on FDI

\begin{tabular}{|c|c|c|c|c|}
\hline \multicolumn{5}{|c|}{ Lower Middle Income Countries } \\
\hline \multirow{2}{*}{ Political Risk Components } & \multicolumn{2}{|c|}{ One-way Fixed } & \multicolumn{2}{|c|}{ Two-way Fixed } \\
\hline & Sig. & Insig. & Sig. & Insig. \\
\hline Government Stability & $-0.38 * * *$ & & $-0.21 * *$ & \\
\hline Socioeconomic Conditions & & 0.16 & $-0.40 * * *$ & \\
\hline Investment Profile & $-0.27 * * *$ & & & -0.06 \\
\hline Internal Conflict & $-0.22 * * *$ & & $-0.23 * * *$ & \\
\hline External Conflict & & -0.04 & & -0.03 \\
\hline Corruption & & -0.05 & & -0.16 \\
\hline Military in Politics & & 0.12 & & -0.01 \\
\hline Religion in Politics & $-0.28 * * *$ & & $-0.26 * * *$ & \\
\hline Law and Order & $-0.45 * * *$ & & $-0.54 * * *$ & \\
\hline Ethnic Tensions & $-0.25 * * *$ & & $-0.17 * *$ & \\
\hline Democratic Accountability & $-0.21 * * *$ & & $-0.26 * * *$ & \\
\hline Bureaucratic Quality & & -0.12 & $-0.29 * * *$ & \\
\hline
\end{tabular}

\subsection{Lower Middle Income Countries}

Similar to the reporting of the previous tables, Table 4 presents the review of the results for the lower middle-income countries (LMICs) and their respective regressions. GDP and Openness are positively correlated at $1 \%$ significance level with FDI for all the models in this group of countries. The results for the LMICs support the hypothesis of the paper strongly. Most of the indicators for both One-Way and Two-Way Fixed Effects models are significant and negative at 1\% significant level. Only Corruption, Military in Politics, Socioeconomic Conditions, External Conflict and Bureaucratic Quality showed insignificant results. The reasoning could be that the data for these indicators might have been too volatile, which rendered the results to be insignificant. The implication of the analysis is that political risk indicators are more relevant in these countries in comparison to other countries around the world. Also, their negative coefficients are higher for most indicators, indicating the hypothesis of negative relationship between political risk and FDI to be strongly supported for these countries.

\subsection{Low Income Countries}

For the LICs, Government Stability and External Conflict have shown significant negative results in One-Way Fixed Effects model. This is evident in Table 5, which presents a summary of the regression results of the low-income countries (LICs). On the other hand, External Conflict, Religion in Politics and Bureaucratic Quality has shown negative and significant results in Two-Way Fixed Effects model. For the developing countries, religion and bureaucracy are more pressing issues and explain why such indicators have shown negative results. Other indicators have shown either insignificant results or positive significance (Investment Profile, Internal 
Conflict, Corruption and Military in Politics), possibly signifying that for the LICs, other factors play a greater role in determining the inflows of FDI, while at the same time data volatility cannot also be ignored.

Table 5. Summary of results of the parameter estimates of political risk indicators on FDI

\begin{tabular}{|c|c|c|c|c|}
\hline \multicolumn{5}{|c|}{ Low Income Countries } \\
\hline & One-way Fixed & & Two-way Fixed & \\
\hline Political Risk Components & Sig. & Insig. & Sig. & Insig. \\
\hline Government Stability & $-0.31 * * *$ & & $0.46^{* * *}$ & \\
\hline Socioeconomic Conditions & $1.71^{* * *}$ & & & -0.29 \\
\hline Investment Profile & & 0.09 & $0.63 * * *$ & \\
\hline Internal Conflict & & -0.07 & $0.21 *$ & \\
\hline External Conflict & $-0.34 * * *$ & & $-0.18 *$ & \\
\hline Corruption & $1.16^{* * *}$ & & $0.50^{* *}$ & \\
\hline Military in Politics & $0.65^{* * *}$ & & $0.43 * *$ & \\
\hline Religion in Politics & & -0.033 & $-0.74 * * *$ & \\
\hline Law and Order & & 0.01 & & -0.15 \\
\hline Ethnic Tensions & & 0.02 & & 0.21 \\
\hline Democratic Accountability & & 0.23 & $0.68 * * *$ & \\
\hline Bureaucratic Quality & & 0.35 & $-0.45^{* *}$ & \\
\hline
\end{tabular}

\section{Conclusion}

With FDI's cosmic importance in the economics and business arena, numerous studies have been carried out to find the determinants. The current study was performed to shed light on a topic that has not received much attention. Political risk as a determinant of FDI has received attention only recently, though under the narrower meaning - corruption (Habib and Zurawicki, 2002). Thus, this paper presents the raison-d-etre for a detailed analysis of the impact of political risk on FDI, taking different indicators of the former, including corruption.

The regression results of World and HICs show similar results. Government Stability, Socioeconomic Conditions and Investment Profile show negative and significant relationship with FDI in these regions, as was predicted in the hypothesis. However, Corruption and Military in Politics both posited positive relationship with FDI. For the UMICs, a few of the indicators were negative and significant but most of them were positive, indicating that political risk indicators does not pose a significant influence in these countries as the trend in FDI for these countries has been largely upward-sloping. The hypothesis was supported most strongly for the LMIC sub-division. Most of the indicators were negative and significant with their coefficients being higher than in the other regions, implying that political risk is a greater threat in the LMICs in comparison to the rest of the World. Evidence of religion and bureaucracy having a negative impact on FDI was observed very strongly for the LICs.

Political risk factors are difficult to quantify. Most studies thus far have used a particular form of political risk, the mostly commonly used proxy being corruption, to explain its adverse effects on FDI and other economic forces. However, using the ICRG index, this study has empirically deduced that political risk factors play an important role in determining FDI inflows. In this context, the government of respective countries, particularly in the LMICs, should try to contain political risks to the furthest extent since the indicators conclude that the LMICs are more prone to political risks and uncertainties. However, different regression results for different groups of countries indicate that caution must be adopted to deal with risk factors that pertain to a particular country in order to properly utilize a country's potential.

Since the political indicators in the study are categorized, it is advantageous to identify the different types of political risks which are characteristic of the different sub-divisions. It is also important that political parties, other stakeholders and bureaucrats in these countries take into account the fact that aggravation of political situations in the countries would lead to an overall negative impact. The consensus, disregarding any region or country, should be to reduce political risks and uncertainties since political instability play an important role in the determination of FDI and consequently, the long-run economic performance of a country.

\section{References}

Aitken, B. J., \& Harrison, A. E. (1999). Do domestic firms benefit from foreign investment? Evidence from Venezuela. American Economic Review, 89(3), 605-618. http://dx.doi.org/10.1257/aer.89.3.605

Busse, M., \& Hefeker, C. (2007). Political risk, institutions, and foreign direct investment. European Journal of 
Political Economy, 23(2), 397-415. http://dx.doi.org/10.1016/j.ejpoleco.2006.02.003

Click, R. W. (2005). Financial and political risks in US direct foreign investment. Journal of International Business Studies, 36(5), 559-575. http://dx.doi.org/10.1057/palgrave.jibs.8400157

Dunning, J. H. (1993). Multinational enterprises and the global economy. Addison-Wesley Publishing Company, Reading.

Dunning, J. H. (1998). Location and the multinational enterprise: A neglected factor. Journal of International Business Studies, 29(1), 45-66. http://dx.doi.org/10.1057/palgrave.jibs.8490024

Findlay, R. (1978). Some aspects of technology transfer and direct foreign investment. American Economic Review, 68(2), 275-279.

Froot, K. A., \& Stein, J. (1991). Exchange rates and foreign direct investment: An imperfect capital markets approach. Quarterly Journal of Economics, 106(4), 1191-1217. http://dx.doi.org/10.2307/2937961

Getz, K. A., \& Volkema, R. J. (2001). Culture, perceived corruption and economics. Business \& Society, 40(1), 7-30. http://dx.doi.org/10.1177/000765030104000103

Gujarati, D. N. (2003). Basic Econometrics. New York: McGraw-Hill/Irwin.

Habib, M., \& Zurawicki, L. (2002). Corruption and foreign direct investment. Journal of International Business Studies, 33(2), 291-307. http://dx.doi.org/10.1057/palgrave.jibs.8491017

Hayakawa, K., Kimura, F., \& Lee, H-H. (2011). How does country risk matter for foreign direct investment. Institute of Developing Economics Discussion Paper No. 281.

Hines, J. (1995). Forbidden payments: Foreign bribery and American business after 1977. Working Paper. National Bureau of Economic Research.

Howell, L. D. (2001). The handbook of country and political risk analysis. The PRS Group, East Syracuse, New York.

Mauro, P. (1995). Corruption and growth. Quarterly Journal of Economics, 110(3), 681-712. http://dx.doi.org/10.2307/2946696

Nye, J. S. (1979). Corruption and political development: A cost-benefit analysis. In M. Ekpo (Ed.), Bureaucratic corruption in Sub-Saharan Africa: Causes, consequences and controls (pp. 57-79). Washington: University Press of America.

OECD, (2000). Main determinants and impacts of foreign direct investment on China's economy. Working Papers on International Investment, China.

Penn World Table. Center for international comparisons of production, income and prices. University of Pennsylvania.

Rappaport, J. (2000). How does openness to capital flows affect growth? Federal Reserve Bank of Kansas City: Mimeo.

Reuber, G. L., Crookel, H., Emerson, M., \& Hammonno, G. (1973). Private foreign investment in development. Oxford: Clarendon Press.

Romer, P. (1993). Idea gaps and object gaps in economic development. Journal of Monetary Economics, 32(3), 543-573. http://dx.doi.org/10.1016/0304-3932(93)90029-F

The Political Risk Services Group. (2012, February 05) International country risk guide methodology. Retrieved from http://www.prsgroup.com/ICRG_Methodology.aspx .

United Nations Conference on Trade and Development. (2012, February 05). Retrieved from http://unctadstat.unctad.org/ReportFolders/reportFolders.aspx?sRF_ActivePath=p,5\&sRF_Expanded=,p,5

Wei, S. J. (2000). How taxing is corruption on international investors? Review of Economics and Statistics 82(1), 1-11. http://dx.doi.org/10.1162/003465300558533

World Bank GDP. (2012, February 08). Retrieved from http://data.worldbank.org/indicator/NY.GDP.MKTP.CD

World Bank. (1997a). Private capital flows to developing countries: The road to financial integration. Washington, D.C..

World Bank. (1997b). Global development finance 1997. Washington, D.C..

Notes 
Note 1 . Political risk is defined as the possibility that political events in a country will affect the business climate and investors will not make as much money as expected (Howell, 2001).

Note 2. Data collected from UNCTAD.

Note 3. OECD, 2000.

Note 4. Data collected from the World Bank .

Note 5. Taken from Penn World Table.

\section{Glossary}

BoP-Balance of Payment

CPI-Corruption Perception Index

FDI-Foreign Direct Investment

GDP-Gross Domestic Product

GNP-Gross National Product

HICs-High-income countries

ICRG-International Country Risk Guide

LICs-Low income countries

LM-Breusch-Pagan Lagrange Multiplier

LMICs-Lower middle-income countries

MNCs-Multinational Companies

OLS-Ordinary Least Square regression

PR-Political Risk

ROA-Return on Assets

UMICs-Upper middle-income countries

USD-United States Dollar 


\section{Appendix}

Classification of countries according to GDP/Capita (according to World Bank classification)

\begin{tabular}{|c|c|c|c|}
\hline $\begin{array}{l}\text { High-income economies } \\
(\$ 12,276 \text { or more })\end{array}$ & $\begin{array}{c}\text { Upper-middle-income } \\
\text { economies }(\$ 3,976-\$ 12,275)\end{array}$ & $\begin{array}{c}\text { Lower-middle-income } \\
\text { economies }(\$ 1,006-\$ 3,975)\end{array}$ & $\begin{array}{c}\text { Low-income economies }(\$ 1,005 \\
\text { or less) }\end{array}$ \\
\hline Australia & Argentina & Angola & Bangladesh \\
\hline Austria & Botswana & Bolivia & Burkina Faso \\
\hline The Bahamas & Brazil & Cameroon & Congo, DR \\
\hline Bahrain & Chile & Congo & Guinea \\
\hline Belgium & China & Cote d'Ivoire & Guinea-Bissau \\
\hline Canada & Colombia & Egypt & Kenya \\
\hline Denmark & Costa Rica & El Salvador & Liberia \\
\hline Finland & Cuba & Ghana & Madagascar \\
\hline France & Ecuador & Guatemala & Malawi \\
\hline Germany & Jamaica & Honduras & Mali \\
\hline Greece & Jordan & India & Mozambique \\
\hline Iceland & Malaysia & Indonesia & Niger \\
\hline Ireland & Mexico & Morocco & Sierra Leone \\
\hline Israel & Panama & Nicaragua & Togo \\
\hline Italy & Peru & Nigeria & Zimbabwe \\
\hline Japan & South Africa & Pakistan & \\
\hline Kuwait & Thailand & Papua New Guinea & \\
\hline Malta & Tunisia & Paraguay & \\
\hline Netherlands & Turkey & Philippines & \\
\hline New Zealand & Uruguay & Senegal & \\
\hline Norway & Venezuela & Sri Lanka & \\
\hline Oman & & Sudan & \\
\hline Portugal & & Syria & \\
\hline Qatar & & Vietnam & \\
\hline Saudi Arabia & & Zambia & \\
\hline \multicolumn{4}{|l|}{ Singapore } \\
\hline \multicolumn{4}{|l|}{ Spain } \\
\hline \multicolumn{4}{|l|}{ Sweden } \\
\hline \multicolumn{4}{|l|}{ Switzerland } \\
\hline \multicolumn{4}{|l|}{ Trinidad and Tobago } \\
\hline \multicolumn{4}{|l|}{ United Arab Emirates } \\
\hline \multicolumn{4}{|l|}{ United Kingdom } \\
\hline United States & & & \\
\hline
\end{tabular}

\section{Copyrights}

Copyright for this article is retained by the author(s), with first publication rights granted to the journal. This is an open-access article distributed under the terms and conditions of the Creative Commons Attribution license (http://creativecommons.org/licenses/by/3.0/). 